\title{
Correction to: The common use of improper control diets in diet-induced metabolic disease research confounds data interpretation: the fiber factor
}

Michael A. Pellizzon ${ }^{*}$ and Matthew R. Ricci

\section{Correction}

Following publication of the original article [1] the authors noticed that the pie chart figure contains percentages $(41 \%, 41 \%, 19 \%)$ that are slightly off given they don't add to 100 . They should instead read $40.6 \%$, $40.6 \%, 18.8 \%$.

Received: 12 March 2018 Accepted: 12 March 2018

Published online: 28 March 2018

\section{Reference}

1. Pellizzon MA, Ricci MR. The common use of improper control diets in dietinduced metabolic disease research confounds data interpretation: the fiber factor. Nutr Metab. 2018;15:3. https://doi.org/10.1186/s12986-018-0243-5.

\footnotetext{
*Correspondence: michael.pellizzon@researchdiets.com

Research Diets, Inc, 20 Jules Lane, New Brunswick, NJ 08901, USA
} 